\title{
POTENSI DAN DISTRIBUSI SPASIAL IKAN DEMERSAL DI LAUT JAWA (WPP NRI-712) DENGAN MENGGUNAKAN TEKNOLOGI HIDROAKUSTIK
}

\section{POTENTIAL AND SPATIAL DISTRIBUTION OF DEMERSAL FISH IN JAWA SEA (FMA NRI-712) BY USING HYDROACOUSTIC TECHNOLOGY}

\author{
Asep Ma'mun ${ }^{\text {* }}$, Asep Priatna1, Suwarso', dan M. Natsir ${ }^{2}$ \\ ${ }^{1}$ Balai Riset Perikanan Laut, Cibinong - Bogor \\ ${ }^{2}$ Pusat Riset Perikanan-Ancol, Jakarta \\ *E-mail: asepmamun@gmail.com
}

\begin{abstract}
One of the efforts to manage sustainable fisheries requires information on potential and distribution patterns of fish resources in the waters. This study aims to spatially describe the distribution of fish and calculate the potential resources of demersal fish in WPP NRI 712 (Java Sea) by hydroacoustic methods, and see changes in fish biomass in the period 2011-2017. The results showed that the distribution of demersal fish spread in several locations in the northern waters of Cirebon, the waters of east Lampung, south of Tanjung Puting National Park and the Thousand Islands. Demersal fish resources detected were dominated by fish size with a length range of $30-31 \mathrm{~cm}$ with five demersal fish resource cohorts. Demersal fish biomass is 875,463 tons, with an average fish density of 117.87 $\mathrm{kg} / \mathrm{km}^{3}$. The sustainable potential of demersal fish is 437,732 tons/year or an increase of $36.6 \%$ from the potential in 2015. The average density of fish and biomass has increased compared to the previous year. One of the factors is because there is time for fish to recover resources naturally. The implementation of management policies in the recovery and utilization efforts needs to be carried out to create sustainable and sustainable fisheries.
\end{abstract}

Keyword: biomass, distribution, demersal fish, hidroacoustics, potential, WPP NRI 712

\begin{abstract}
ABSTRAK
Salah satu upaya pengelolaan perikanan lestari membutuhkan informasi potensi dan pola penyebaran sumberdaya ikan di perairan. Penelitian ini bertujuan untuk menggambarkan secara spasial distribusi ikan dan menghitung potensi sumber daya ikan demersal di WPP NRI 712 (Laut Jawa) dengan metode hidroakustik, dan melihat perubahan biomassa ikan dalam kurun waktu 2011-2017. Hasil penelitian menunjukkan bahwa distribusi ikan demersal menyebar pada beberapa lokasi di utara perairan Cirebon, perairan Lampung timur, selatan Taman Nasional Tanjung Puting dan Kepulauan Seribu. Sumberdaya ikan demersal yang terdeteksi didominasi oleh ukuran ikan dengan kisaran panjang antara 30-31 cm dengan lima kohort sumberdaya ikan demersal. Biomassa ikan demersal sebesar 875.463 ton, dengan kepadatan ikan rata-rata yaitu $117,87 \mathrm{~kg} / \mathrm{km}^{3}$. Potensi lestari ikan demersal sebesar 437.732 ton/tahun atau meningkat $36,6 \%$ dari potensi tahun 2015. Kepadatan ikan rata-rata dan biomassa mengalami peningkatan jika dibandingkan dengan tahun sebelumnya. Salah satu faktornya yaitu karena adanya waktu untuk ikan dapat melakukan pemulihan sumberdaya secara alami. Penerapan kebijakan pengelolaan dalam upaya pemulihan dan pemanfaatan perlu dilakukan untuk menciptakan perikanan yang lestari dan berkesinambungan.
\end{abstract}

Kata kunci : potensi, biomassa, sebaran, ikan demersal, hidroakustik, WPP NRI 712

\section{PENDAHULUAN}

Perikanan lestari dan berkelanjutan tidak luput dari manajemen pengelolaan perikanan yang baik dan terencana.
Pengelolaan perikanan yang berkelanjutan harus memiliki kondisi perikanan yang terkontrol dan terukur terhadap upaya pemanfaatanya. Berdasarkan Permen KP No. 18 tahun 2014 tentang Wilayah Pengelolaan 
Perikanan Negara Republik Indonesia, WPPNRI 712 meliputi perairan Laut Jawa. Masyarakat pesisir pantai Laut Jawa umumnya sebagai nelayan yang menjadikan sumberdaya laut sebagai sumber ekonomi utama. Sebagian besar nelayan termasuk kedalam nelayan perikanan tangkap, dengan pertambahan jumlah nelayan tangkap yang terus meningkat. Tahun 2010-2014 tercatat pertumbuhan nelayan tangkap mencapai 3,78\% pertahun (DJPT, 2015).

Tingginya aktivitas perikanan tangkap perlu diiringi dengan pengelolaan yang baik secara berkesinambungan. Hilborn et al. (2005) menyatakan bahwa perikanan tangkap perlu dikelola dalam rentang struktur kebijakan yang luas dan termasuk juga pemberian hak atas sumberdaya ikan yang memperhatikan aspek moral sosial. Konteks pengelolaan perikanan skala kecil, Cinner et al. (2013) menyatakan bahwa perlunya pendekatan institusi untuk mengatasi problem klasik perikanan seperti kegagalan dalam tata kelola, stok ikan yang collaps dan mengurangi kemiskinan. Berlakunya Permen Nomor 2/PERMEN-KP/2015 tentang pelarangan penggunaan alat tangkap jenis pukat, merupakan salah satu upaya pemerintah dalam pengelolaan yang lestari dan memperbaiki kondisi stok ikan.

Nilai biomassa merupakan unsur utama dalam penentuan stok, potensi perikanan dan sebagai data dasar dalam penentuan upaya pengelolaan perikanan kedepan. Salah satu metode yang dapat digunakan untuk menghitung biomassa ikan adalah dengan menggunakan survei teknologi hidroakustik (MacLennan and Simmonds, 2005). Ikan demersal merupakan kelompok ikan yang mengalami tekanan penangkapan yang cukup tinggi di Laut Jawa dan kini area operasi penangkapanya bergeser ke daerah perairan yang lebih dalam hingga kedalaman $40 \mathrm{~m}$ (Badrudin, 2011). Hasil pendugaan Badrudin et al. (2011) sumber daya ikan demersal di perairan pantai sudah mengalami overfishing yang mengarah kepada depleted.
Potensi ikan demersal pada tahun 2010 dan 2013, sebelum moratorium dilaksanakan tercatat melalui Permen-KP yaitu sebesar 375.200 ton/th dan 354.692 ton/th (KKP, 2011; KKP, 2014). Biomassa hasil survei kajian stok tahun 2015 yaitu sebesar 640.863 ton dengan nilai potensi ikan demersal mencapai 320.432 ton/th (KKP, 2016). Penelitian ini diharapkan dapat dijadikan sebagai dasar untuk pengelolaan perikanan yang efisien, lestari dan berkelanjutan, maka dari itu penelitian ini bertujuan untuk menggambarkan kondisi ikan demersal di WPP NRI 712 yaitu distribusi ukuran, sebaran ikan demersal serta untuk melihat pola perubahan biomassa sebelum dan sesudah moratorium alat tangkap pukat berlangsung.

\section{METODE PENELITIAN}

\subsection{Pengumpulan Data}

Penelitian dilaksanakan pada tanggal 17 Oktober sampai dengan 11 November 2017 dengan menggunakan KR. Bawal Putih III yang dilengkapi dengan peralatan hidroakustik untuk keperluan estimasi stok sumberdaya ikan secara langsung. Akuisisi data akustik menggunakan multibeam echosounder Simrad ME 70 dengan rentang frekuensi $70-120 \mathrm{kHz}$, sedangkan data yang digunakan untuk penelitian ini yaitu frekuensi $116 \mathrm{kHz}$. Transduser berada pada lunas kapal. Konfigurasi yang digunakan selama proses akusisi data menggunakan 5 beam pada rentang frekuensi minimal $70 \mathrm{kHz}$ dan maksimal $120 \mathrm{kHz}$. Jarak antar frekuensi pada masing-masing beam ditentukan secara linier dengan cara menentukan jumlah frekuensi yang diinginkan, dimana acuan nilai tengah dari main lobe optimal terhadap kedalaman rata-rata secara logaritmik yaitu pada frekuensi 74,2 kHz. Mempertimbangkan rata-rata kedalaman maksimal perairan Laut Jawa sekitar $60 \mathrm{~m}$, maka durasi pulsa yang digunakan adalah 384s. Lebar sudut bukaan (opening beam angle) pada beam utama (74,2 Khz) adalah 4,6 untuk athwarth 
side dan 4,7 untuk along side, sedangkan untuk keseluruhan bukaan sudut beam adalah $98^{\circ}$. Data yang digunakan dalam penelitian ini adalah data hidroakustik frekuensi 116 $\mathrm{kHz}$ yang dinilai dapat memberikan resolusi dan gambaran target ikan yang jelas apabila objek berdekatan atau hampir overlapping dengan dasar perairan.

Data yang dikumpulkan adalah nilai dari target strength (TS), area backscattering coeficient $\left(\mathrm{s}_{\mathrm{A}}\right)$ yang berfungsi sebagai dasar untuk proses kuantifikasi dengan echo integrator (Shabangu et al., 2014; Ma'mun et al., 2017). Lintasan kapal untuk pengumpulan data hidroakustik menggunakan transek systematic paralel transek dengan panjang lintasan total mencapai $3.462 \mathrm{~km}$, kecepatan rata-rata kapal antara 5-6 knot. Jalur akusisi data pada Gambar 1.

Hasil pengamatan hidroakustik (echogram) dicatat dalam bentuk file-file digital yaitu *.raw. Keluaran data akustik yaitu berupa distribusi data target strength (TS) dalam satuan desibel sebagai indeks ukuran ikan, serta data volume backscattering strength (SV) sebagai indeks kepadatan dari suatu kumpulan target ikan yang terdeteksi. Validasi bobot dan ukuran panjang ikan menggunakan data hasil tangkapan trawl pada lokasi-lokasi stasiun yang telah ditentukan. Beberapa jenis ikan hasil tangkapan trawl (kerapu, kuniran, kue dan pepetek), ikan kuniran (U. sulphureus) merupakan ikan dominan yang tertangkap hampir pada semua stasiun. Oleh karena itu, ikan kuniran (U. sulphureus) dianggap mewakili jenis ikan demersal yang digunakan untuk perhitungan hubungan panjang berat sebagai faktor konversi ke biomassa ikan. Banyaknya data ikan yaitu sebanyak 785 ekor dari hasil tangkapan dari beberapa stasiun penelitian.

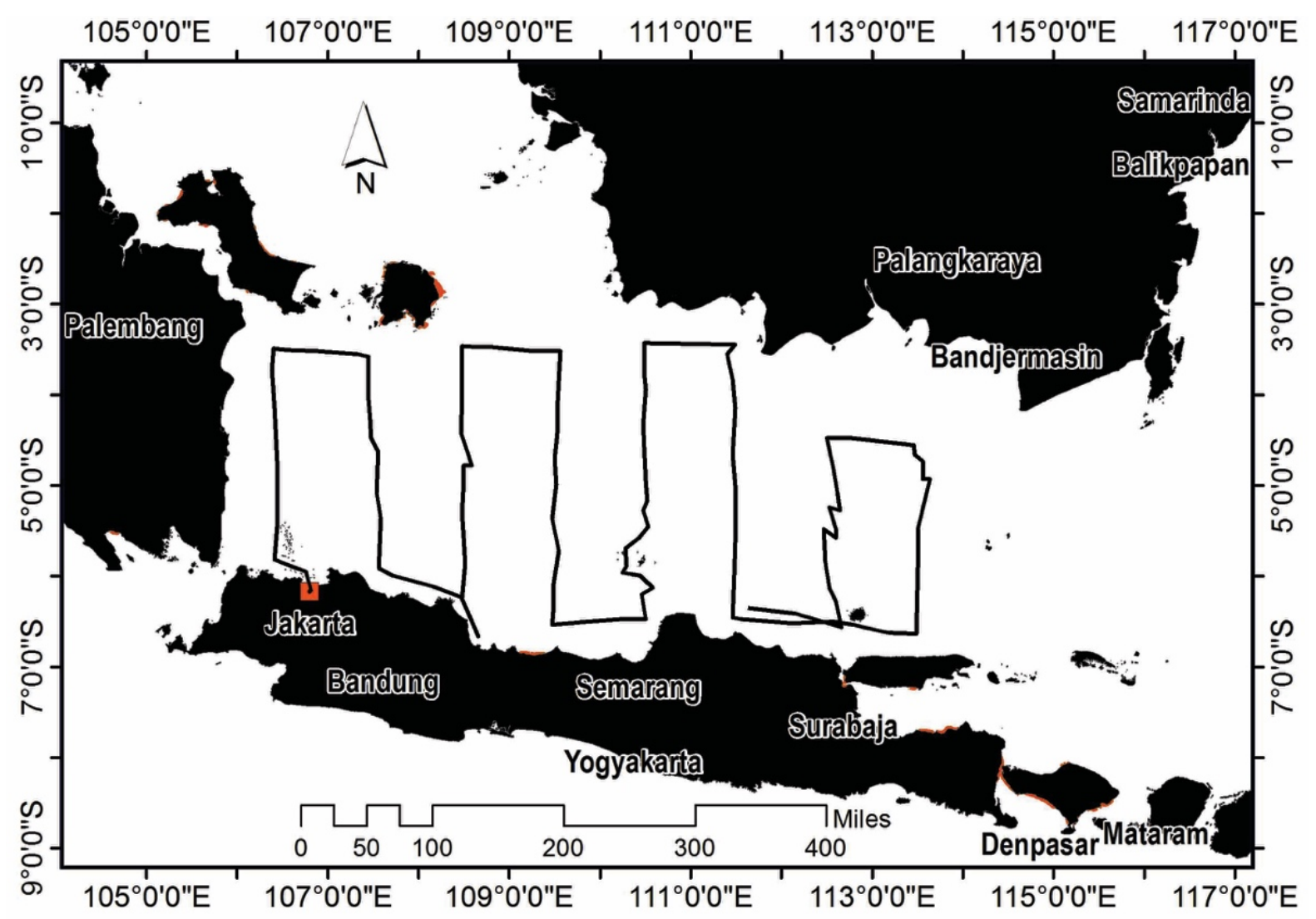

Gambar 1. Jalur transek hidroakustik untuk estimasi sumberaya ikan. 


\subsection{Pengolahan dan Analisis Data}

Data akustik multibeam diolah dengan menggunakan software SONAR ver.6 dengan Elementary Distance Sampling Unit (EDSU) sekitar $1 \mathrm{~nm}$. Tidak berbeda jauh dengan data split beam data multibeam yang digunakan yaitu data hasil ekstraksi berupa nilai area back scattering coeficient $\left(\mathrm{s}_{\mathrm{A}}, \mathrm{m}^{2} / \mathrm{nmi}^{2}\right)$ dan distribusi nilai target strength (TS) ikan tunggal dalam satuan decibel $(\mathrm{dB})$ yang merupakan indeks refleksi ukuran ikan tunggal.Sebaran komposisi berdasarkan ukuran ikan dinyatakan dalam target strength (TS) dengan satuan $\mathrm{dB}$ yang dapat dikonversikan sebagai ukuran panjang ikan.

Hubungan TS dan obs (backscattering cross-section, $\mathrm{m}^{2}$ ) dihitung berdasarkan rumus dari MacLennan and Simmonds (2005) yaitu: $\mathrm{TS}=10 \log \sigma \mathrm{bs}$, Persamaan untuk densitas ikan ( $\rho \mathrm{A}$, ind $\left./ \mathrm{nmi}^{2}\right)$ adalah $\rho \mathrm{A}$ $=\mathrm{sA} / \sigma \mathrm{bs}$. Panjang ikan (L) berhubungan dengan $\sigma b s$ yaitu $: \sigma b s=a L^{b}$. Konversi nilai TS menjadi ukuran panjang (L) diperoleh dari $\mathrm{TS}=20 \log \mathrm{L}+\mathrm{A}$. Dimana A adalah nilai TS untuk $1 \mathrm{~cm}$ panjang ikan (normalized TS). Ikan demersal digunakan persamaan TS $=20 \log \mathrm{L}-68$ (Hjellvik et al., 2003) berupa formulasi dari ikan Kod (Gymnocephalus cernuus). Menurut Hile (1936) dalam Effendi (2002), hubungan panjang (L) dan bobot (W) dari suatu spesies ikan yaitu: $\mathrm{W}=\mathrm{aL}^{\mathrm{b}}$. Menurut Simmonds andMac Lennan (2005) persamaan panjang dan bobot untuk mengkonversi panjang dugaan menjadi bobot dugaan adalah:

$$
\begin{aligned}
& \mathrm{Wt}=\mathrm{a}\left\{\sum_{1}^{i}\left\{\mathrm{ni}(\mathrm{Li}+\Delta \mathrm{L} / 2)^{\mathrm{b}+1}-(\mathrm{Li}-\Delta \mathrm{L} / 2)^{\mathrm{b}+1}\right\} /\right. \\
& \{(\mathrm{b}+1) \Delta \mathrm{L}\}\} \ldots \ldots \ldots \ldots \ldots \ldots \ldots \ldots \ldots \ldots \ldots \ldots \ldots \ldots \ldots \ldots \ldots \ldots \ldots \ldots \ldots
\end{aligned}
$$

Keterangan: $\mathrm{Wt}=$ bobot total (gram); $\Delta \mathrm{L}=$ selang kelas panjang $(\mathrm{cm}) ; \mathrm{Li}=$ nilai tengah dari kelas panjang ke-i $(\mathrm{cm})$; ni $=$ jumlah individu pada kelas ke-I; a, b = konstanta untuk spesies tertentu.

Analisis sebaran spasial sumberdaya ikan, kepadatan ikan yang terdeteksi selama akuisisi data akustik dinyatakan dalam nilai densitas relatif (jumlah individu per luasan area, dengan satuan ikan $/ \mathrm{m}^{3}$ ). Sebaran komposisi berdasarkan ukuran ikan dinyatakan sebagai estimasi ukuran rata-rata didasarkan pada nilai TS yang dinyatakan dalam satuan cm (Yong and Ha, 1998; Shabangu et al, 2014; Ma'mun et al., 2017). Nilai TS tersebut kemudian akan digunakan sebagai dasar pembagian kelompok sumber daya, mengingat nilai TS pada setiap individu memiliki nilai yang berbeda-beda (Korneliussen et al.,2009; Kim et al., 1998; Lee, 2012). Batasan kedalaman untuk ikan demersal dalam pengolahan data hidroakustik yaitu $5 \mathrm{~m}$ diatas area dead zone akustik dikarenakan ruaya horizontal ikan demersal tidak jauh dari dasar perairan; sedangkan dead zone yang nilainya dapat dihitung dari nilai perambatan suara terhadap waktu dan jarak pancaran merupakan jarak minimal kemampuan dari instrumen untuk membedakan ikan dan dasar perairan (Kloser et al. 1996; Priatna, 2014). Adapun asumsi yang digunakan untuk struktur ukuran ikan adalah perbedaan species ikan dianggap tidak memberikan pengaruh nyata. Ukuran ikan yang digunakan dalam sampel hasil tangkapan yaitu fork length (FL). Ikan demersal memiliki ukuran 5-64 cm (TS -60 s/d -37 dB). Hasil analisis ditampilkan dalam bentuk grafik dan sebaran spasial berdasarkan posisi geografis.

Asumsi kondisi lingkungan tidak berbeda maka tingkat kematian alami ikan tidak bervariasi, sehingga dengan cara mengalikan densitas ikan hasil analisis data hidroakustik dengan luasan keseluruhan daerah kajian (A) akan didapatkan biomassa (Bo) atau disebut dengan istilah standing stock di perairan tersebut dengan persamaan: $B o=A \times \rho$ dimana $\rho=$ densitas ikan (Sparre and Venema, 1998). Gulland (1983) menyatakan bahwa dengan mengambil separuh dari biomassa yang ada maka sumber daya ikan tersebut diperkirakan akan lestari, hal tersebut diharapkan keberadaan (availability) sumber daya ikan tersebut akan 
berlanjut. Pernyataan tersebut kemudian dijadikan dasar untuk menkonversi total biomassa dari nilai potensi dari survei tahun sebelumnya.

\section{HASIL DAN BAHASAN}

\subsection{Hasil}

\subsubsection{Stuktur Ukuran Ikan}

Hasil pengamatan akustik yang diturunkan dari nilai target strength menunjukkan bahwa ikan demersal didominasi pada selang modus ukuran $30-31 \mathrm{~cm}$ (Gambar 2a) dengan jumlah sampel sebanyak 2154. Ukuran ikan demersal hasil dari tangkapan saat survei yang berlangsung kurang lebih dalam rentang waktu survei yang sama pada titik yang telah ditentukan, menunjukkan bahwa komposisi ukuran ikan demersal didominasi oleh ikan dengan ukuran kelas modus 30-31 cm dengan jumlah sampel 785 (Gambar 2).

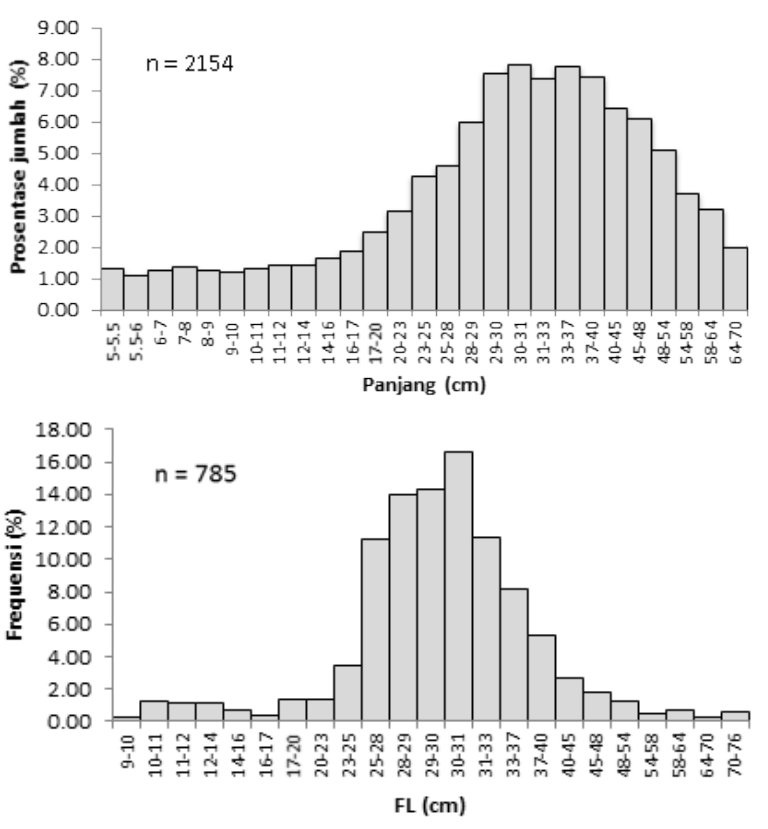

Gambar 2. Komposisi ukuran ikan pelagis kecil hasil observasi akustik (atas) dan hasil tangkapan (bawah).

Kedua modus tersebut dapat disimpulkan bahwa kelompok ikan yang terdeteksi oleh hidroakustik dan hasil tangkapan tidak jauh berbeda yaitu ikan demersal yang sama.

Hasil pengamatan ikan demersal pada saat survei eksplorasi, menunjukkan bahwa jenis ikan demersal yang dominan tertangkap adalah ikan kuniran (U. sulphureus), model hubungan panjang dan bobot dari ikan tersebut yaitu $\mathrm{W}=0.02 * \mathrm{~L}^{2.861}$. Jenis ikan demersal ini merupakan ikan yang banyak didaratkan oleh nelayan di perairan WPP NRI 712. Persentase jumlah ikan kuniran ( $U$. sulphureus) yang mewakili data untuk konversi ke bobot yaitu sebesar 36.4\% dari jumlah ikan yang terdeteksi hidroakustik. Data hasil produksi ikan kuniran di WPP NRI 712 pada tahun 2005-2014 menunjukan kenaikan rata-rata pertahunya sebesar 68,62\% (DJPT, 2015). Hasil penelitian Ernawati (2007), menyatakan bahwa komposisi hasil tangkapan dominan di perairan utara Jawa Tengah berturut-turut adalah famili Leiognathidae, Synodontidae, Nemipteridae, dan Mullidae. Boer et al. (2001) dan Widodo et al. (1998) mengemukakan bahwa terdapat berpuluh jenis ikan demersal di perairan Indonesia.

\subsubsection{Distribusi Spasial Ikan Demersal}

Distribusi jenis ikan demersal secara spasial digambarkan dengan lingkaran berskala berwarna merah, apabila semakin besar menunjukan densitas tersebut memiliki nilai kepadatan yang tinggi (Gambar 3). Distribusi ikan demersal menyebar pada beberapa lokasi antara lain banyak ditemukan di daerah Kepulauan Seribu, utara Serang, pesisir utara Cirebon serta di beberapa daerah lainya yaitu perairan timur Lampung, bagian selatan Kalimantan di sekitar Taman Nasional Tanjung Puting dan timur laut Banjarmasin. Densitas ikan demersal yang terdeteksi di WPP NRI 712, di beberapa lokasi memiliki densitas ikan yang cukup besar dibandingkan lokasi lainya. Densitas ikan demersal cukup besar ditemukan di perairan Kepulauan Seribu dan utara perairan Cirebon, dengan nilai densitas yaitu $1.765,26 \mathrm{~kg} / \mathrm{km}^{3}$ dan $1.470,82 \mathrm{~kg} / \mathrm{km}^{3}$. 


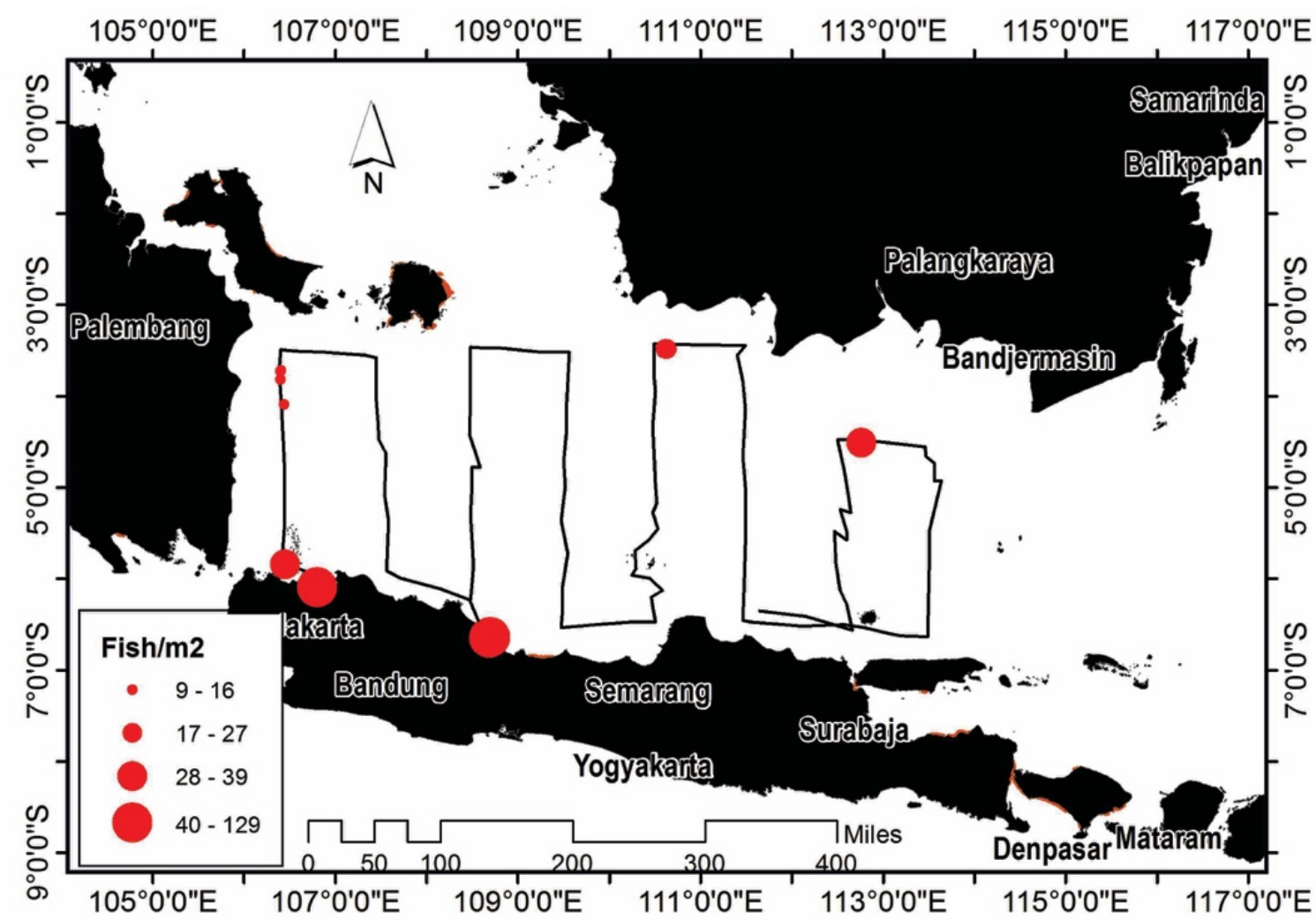

Gambar 3. Sebaran mendatar densitas ikan demersal di WPP NRI 712.

Daerah perairan Lampung timur nilai densitas ikan yaitu $181,86 \mathrm{~kg} / \mathrm{km}^{3}$ (Gambar 3). Bagian selatan Taman Nasional Tanjung Puting nilai densitas ikan demersal tertinggi yaitu $208,46 \mathrm{~kg} / \mathrm{km}^{3}$, sedangkan pada daerah timur laut perairan Banjarmasin yaitu 235,22 $\mathrm{kg} / \mathrm{km}^{3}$.

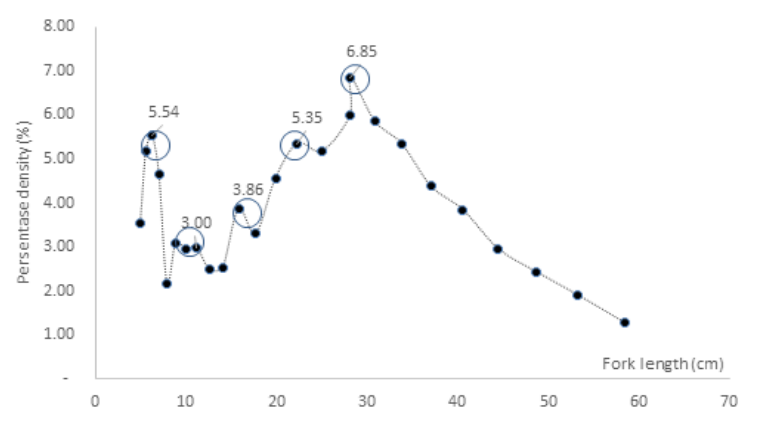

Gambar 4. Kelompok densitas ikan demersal di WPP NRI 712.

Nilai densitas ikan yang diperoleh terhadap ukuran panjang ikan diperoleh bahwa terdapat lima kelompok ukuran ikan pada wilayah WPP NRI 712, Hal ini didasarkan kepada banyaknya kohort yang terbentuk pada grafik. Kelompok ikan yang terbentuk menyebar merata pada rentang ukuran panjang ikan demersal dari analisis data hidroakustik yaitu pada ukuran (5-53,3 $\mathrm{cm})$ atau pada rentang nilai target strength ($60 \mathrm{~s} / \mathrm{d}-43 \mathrm{~dB})$ dengan bobot (2,7-2416 g). Gambar 4.

\subsubsection{Kepadatan Stok, Biomassa dan Potensi Lestari}

Estimasi biomassa dan kepadatan stok ikan, ukuran ikan demersal yang dihitung didasarkan pada ukuran TS pada kisaran -60 sampai $-37 \mathrm{~dB}$ atau pada ukuran panjang 5-53,3 cm FL dengan kisaran bobot dari 2,7-2416 gram. Estimasi biomassa dan kepadatan stok yang terdistribusi di perairan WPP NRI 712 dilakukan pada total luasan $414.960 \mathrm{~km}^{2}$, dihitung dari batasan area WPP NRI 712. 
Tabel 2. Komposisi ukuran, biomassa, dan kepadatan stok ikan.

\begin{tabular}{lccccccccc}
\hline Nilai TS (dB) & -60 & -59 & -58 & -57 & -56 & -55 & -54 & -53 & -52 \\
\hline Panjang (cm) & 5,0 & 5,6 & 6,3 & 7,1 & 7,9 & 8,9 & 10,0 & 11,2 & 12,5 \\
Bobot (gram) & 2,7 & 3,7 & 5,2 & 7,2 & 10,0 & 13,9 & 19,4 & 27,0 & 37,6 \\
Komposisi & 1,5 & 1,2 & 1,4 & 1,5 & 1,4 & 1,3 & 1,5 & 1,6 & 1,6 \\
$\begin{array}{l}\text { (\%) } \\
\text { Densitas }\end{array}$ & 0,015 & 0,031 & 0,046 & 0,050 & 0,041 & 0,019 & 0,027 & 0,026 & 0,027 \\
$\begin{array}{l}\text { Biomassa } \\
\text { (ton) }\end{array}$ & 43 & 50 & 83 & 124 & 161 & 209 & 323 & 497 & 672 \\
$\begin{array}{l}\text { Kepadatan } \\
\left(\mathrm{kg} / \mathrm{km}^{3}\right)\end{array}$ & 0,11 & 0,12 & 0,20 & 0,30 & 0,39 & 0,51 & 0,78 & 1,20 & 1,62 \\
\hline
\end{tabular}

Tabel 3. Komposisi ukuran, biomassa, dan kepadatan stok (lanjutan).

\begin{tabular}{lccccccccc}
\hline Nilai TS (dB) & -51 & -50 & -49 & -48 & -47 & -46 & -45 & -44 & -43 \\
\hline Panjang (cm) & 14,1 & 15,8 & 17,7 & 19,9 & 22,3 & 25,0 & 28,1 & 28,2 & 30,9 \\
Bobot (gram) & 52,4 & 73,0 & 101,6 & 141,5 & 197,1 & 274,4 & 382,2 & 385,3 & 500,9 \\
Komposisi & 1,9 & 2,1 & 2,8 & 3,5 & 4,8 & 5,2 & 6,8 & 7,2 & 8,5 \\
$\begin{array}{l}\text { (\%) } \\
\text { Densitas }\end{array}$ & 0,022 & 0,022 & 0,034 & 0,029 & 0,041 & 0,048 & 0,046 & 0,054 & 0,061 \\
Biomassa & 1106 & 1754 & 3235 & 5655 & 1065 & 1596 & 2914 & 3138 & 48070 \\
(ton) & & & & & 1 & 4 & 7 & 8 & \\
$\begin{array}{l}\text { Kepadatan } \\
\left(\mathrm{kg} / \mathrm{km}^{3}\right)\end{array}$ & 2,67 & 4,23 & 7,80 & 13,63 & 25,67 & 38,47 & 70,24 & 75,64 & 115,84 \\
\hline
\end{tabular}

Tabel 4. Komposisi ukuran, biomassa, dan kepadatan stok (lanjutan).

\begin{tabular}{lcccccc}
\hline Nilai TS (dB) & -42 & -41 & -40 & -39 & -38 & -37 \\
\hline Panjang (cm) & 33,8 & 37,0 & 40,6 & 44,4 & 48,7 & 53,3 \\
Bobot (gram) & 651,1 & 846,3 & 1100,0 & 1429,9 & 1858,7 & 2416,0 \\
Komposisi (\%) & 8,8 & 8,3 & 6,9 & 7,0 & 6,8 & 6,2 \\
Densitas & 0,052 & 0,048 & 0,039 & 0,034 & 0,026 & 0,022 \\
Biomassa (ton) & 64600 & 79295 & 108911 & 134909 & 152008 & 186596 \\
Kepadatan & 155,68 & 191,09 & 262,46 & 325,11 & 366,32 & 449,67 \\
$\left(\mathrm{~kg} / \mathrm{km}^{3}\right)$ & & & & & & \\
\hline
\end{tabular}

Densitas ikan rata-rata yang terdeteksi pada area WPP NRI 712 sebesar $0,034 \mathrm{ikan} / \mathrm{m}^{3}$, didominasi oleh ukuran panjang 30,9 $\mathrm{cm}$ dengan persentase $6,85 \%$. Biomassa rata-rata $(\mathrm{Bo} \pm \mathrm{sd})$ yaitu sebesar $36,477 \pm 0,65$ ton dari semua ukuran panjang ikan yang terdeteksi, dengan kepadatan ikan rata-rata yaitu $91,65 \mathrm{~kg} / \mathrm{km}^{3}$. Kepadatan ikan terbesar yaitu $489 \mathrm{~kg} / \mathrm{km}^{3}$ dan yang terkecil yaitu $0,10 \mathrm{~kg} / \mathrm{km}^{3}$. Pola perkembangan kondisi biomassa ikan demersal pada beberapa tahun terakhir dan dari hasil penelitian, dapat dilihat pada Gambar 5. Nilai biomassa ikan demersal pada tahun 2010, 2013, 2015 dan 2017 (hasil penelitian).

Hasil survei biomassa ikan demersal pada tahun 2017 yaitu 875.463 ton. Pada tahun sebelumnya potensi ikan demersal sebesar 375.200 ton/tahun, dengan biomassa sebesar 750.400 ton (2011), tahun 2013 potensi ikan sebesar 354.692 ton/tahun dan biomassanya yaitu 709.384 ton, potensi ikan 
tahun 2015 yaitu 320.432 ton/tahun dengan biomassa sebesar 640.864 ton. Biomassa ikan demersal dari tahun 2011- 2015 mengalami penurunan rata-rata pertahun sebesar $12,1 \%$ dan mengalami kenaikan sebesar 36,6\% pada tahun 2017. Hasil perhitungan biomassa kemudian diestimasi potensi lestari (MSY) ikan demersal pada tahun 2017 yaitu 437.732 ton/tahun.

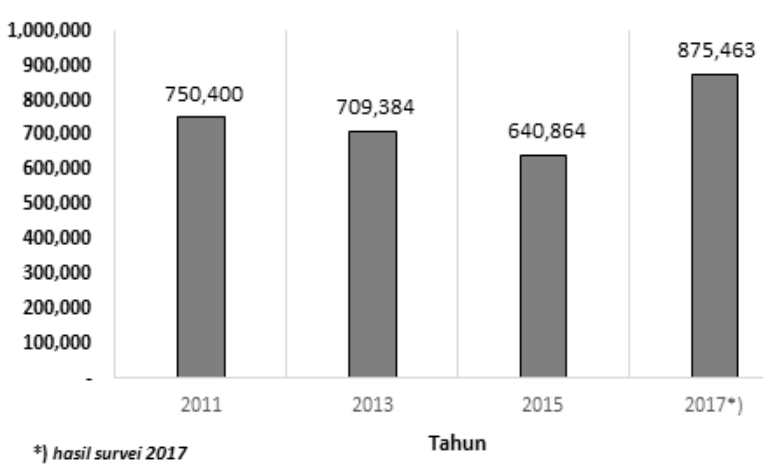

Gambar 5. Biomassa ikan demersal (2011, 2013, 2015 dan 2017).

\subsection{Pembahasan}

Pola sebaran ikan demersal pada wilayah WPP NRI 712 menyebar pada semua daerah yang dilalui survei hingga kedalaman $60 \mathrm{~m}$. Ikan demersal khususnya famili mulidae optimum keberadaanya dapat ditemukan pada kedalaman perairan 40-60 m (Badrudin, 2011). Hasil olahan data hidroakustik diperoleh bahwa ukuran ikan demersal memiliki selang ukuran panjang antara 5-64 cm, hal ini didasarkan dari nilai Targetstrength berdasarkan persamaan TS $=$ $20 \log \mathrm{L}-68$ (Hjellvik et al., 2003). Ukuran ikan demersal dari hasil pengamatan hidroakustik didominasi oleh ukuran 30-31 $\mathrm{cm}$, hal ini sesuai dengan data hasil tangkapan saat survei. Ukuran tersebut kemungkinan besar ikan dalam fase ikan dewasa, hal ini didasarkan pada pengukuran aspek biologi yang diperoleh dimana indeks TKG di dominasi oleh nilai TKG II dan TKG III dari beberapa spesies ikan demersal ekonomis penting yang diperoleh.
Adanya perbedaan jumlah hasil tangkapan dengan data hasil perekaman akustik yang diduga karena adanya pola tingkah laku ikan demersal untuk menghindar dari proses penangkapan, disamping beberapa ikan yang overlapping dengan dasar perairan sehingga ikan dan dasar perairan sulit dibedakan, merupakan faktor lainnya yang mempengaruhi perbedaan nilai tersebut. Tingkah laku penghindaran ikan tersebut merupakan salah satu sumber bias dalam survei perikanan. Reaksi ikan terhadap kapal yang mendekati merupakan suatu variabel dan sulit untuk diprediksi (De Robertis et al., 2012). Menurut Winger et al. (2010), bahwa setiap kapal dan operasi trawl memberikan kombinasi suara yang spesifik saat beroperasi di bawah air.

Sebaran densitas ikan demersal di wilayah WPP NRI 712 menyebar pada beberapa lokasi. Densitas ikan cukup besar ditemukan di utara perairan Cirebon, perairan Lampung timur, selatan Taman Nasional Tanjung Puting dan perairan Kepulauan Seribu dengan nilai densitas terbesar yaitu $1.765,26 \mathrm{~kg} / \mathrm{km}^{3}$. Penyebaran nilai densitas kemungkinan disebabkan faktor lingkungan, substrat dasar atau terumbu karang sebagai tempat mencari makanan. Lokasi-lokasi yang memiliki densitas ikan terbesar pada penelitian ini, umumnya merupakan daerah penangkapan ikan nelayan Pulau Jawa.

Menurut Atmajadan Nugroho (2012) menyatakan bahwa distribusi spasial upaya penangkapan perikanan demersal telah menyebar di hampir seluruh Laut Jawa, terkonsentrasi di Selatan Belitung dan Selatan Kalimantan sampai Selat Makassar. Daerah penangkapan berdasarkan bulan penangkapan terbagi dalam 3 sub area, yaitu: a) perairan timur Sumatera dan selatan Bangka-Belitung yaitu bulan Maret, April, Mei, Juni, Agustus dan November); b) di perairan Selatan Kalimantan (Tanjung Puting dan Tanjung Selatan), yaitu bulan Juli, September dan Oktober, Nopember; dan c) di perairan utara Brebes dilakukan pada bulan Desember. Pemilihan daerah penangkapan 
cantrang tidak dipengaruhi oleh perubahan musim, tetapi lebih dipengaruhi oleh faktor kondisi cuaca dan pengalaman nakhoda (Ernawati et al., 2011). Terdapat lima kelompok ikan yang terdeteksi dengan ukuran kelompok hampir merata, gambaran ini didasarkan kepada banyaknya kohort, yaitu kelompok ikan yang memiliki ukuran yang sama dan berasal dari stok yang sama (Sparre et al, 1998).

Rata-rata biomassa ikan pada WPP NRI 712 mencapai 48.165 ton dengan kepadatan ikan rata-rata $117,87 \mathrm{~kg} / \mathrm{km}^{3}$. Hasil survei pada tahun 2017 menunjukan bahwa rata-rata biomassa dan kepadatanya mengalami kenaikan, dimana hasil tahun 2015 tercatat rata-rata biomassa ikan yaitu 13.553 ton, dengan kepadatan ikan 58,25 $\mathrm{kg} / \mathrm{km}^{3} \quad$ (BRPL, 2015). Meningkatnya kepadatan stok ikan demersal pada beberapa lokasi penelitian diduga karena banyaknya makanan dan kondisi lingkungan yang sesuai dengan kondisi ikan. Makanan yang dimakan oleh ikan dimanfaatkan langsung dalam siklus metabolisme hidupnya yang akan berpengaruh terhadap pertumbuhan, reproduksi, dan tingkat keberhasilan hidup ikan di perairan sehingga ketersediaan makanan disuatu perairan merupakan faktor yang mempengaruhi besar kecilnya populasi ikan di perairan tersebut (Effendi, 2002).

Adanya kecenderungan penurunan potensi lestari ikan demersal pada tahun 2011-2015 terhadap tekanan penangkapan dengan penurunan rata-rata pertahun sebesar $12,1 \%$. Status sumberdaya ikan demersal menunjukan overfishing dan terjadinya degradasi sumberdaya.

Hasil simulasi model laju degradasi sumberdaya ikan demersal disekitar pantai di Kabupaten Indramayu menunjukan pada tahun 2030 masih tetap terjadi degradasi bila tanpa adanya kebijakan perikanan (Yulianto, 2016).

Upaya pemerintah mengeluarkan Permen-KP dalam rangka mengurangi tekanan penangkapan yang cukup tinggi pada tahun 2015, menghasilkan beberapa pe- rubahan kondisi perikanan khususnya nilai potensi lestari (MSY). Hasil perhitungan biomassa ikan dan potensi lestari ikan demersal pada tahun 2016 menurut Komnas Kajiskan (Permen KP No.47 tahun 2016) bila dibandingkan dengan hasil perhitungan tahun 2017 mengalami kenaikan sebesar 36,6\% pada tahun 2017.

Adanya kenaikan nilai potensi lestari hasil perhitungan pada tahun 2017 diduga karena adanya upaya perbaikan kondisi stok baik secara lingkungan maupun dalam regulasi penangkapan yang diberlaku-kan. Penerapan kebijakan pengelolaan dalam upaya pemulihan dan pemanfaatan perlu dilakukan di perairan WPP NRI 712, hal ini untuk menciptakan perikanan lestari dan berkelanjutan di masa yang akan datang.

\section{KESIMPULAN}

Distribusi ikan demersal di Laut Jawa dengan menggunakan metode hidroakustik, bahwa ikan-ikan demersal dapat ditemukan pada rentang ukuran $5-53 \mathrm{~cm}$ yang didominasi oleh ikan demersal dewasa. Keselurahan data hidroakustik yang diperoleh terdapat lima kelompok ikan memiliki ukuran yang sama dari kelompok stok yang sama. Secara spasial distribusi ikan menyebar pada beberapa lokasi antara lain di utara perairan Cirebon, perairan lampung timur, selatan Taman Nasional Tanjung Putting dan Kepulauan Seribu yang sebagian besar merupakan fishing ground nelayan tangkap. Jika dibandingkan dengan tahuntahun sebelumnya (2011-2017), kepadatan ikan rata-rata dan biomassa mengalami peningkatan. Salah satu faktor terjadinya peningkatan ini dikarenakan adanya waktu yang dibutuhkan untuk ikan dapat melakukan pemulihan sumberdaya secara alami terhadap habitat dan lingkunganya. Penerapan kebijakan pengelolaan dalam upaya pemulihan dan pemanfaatan perlu dilakukan untuk menciptakan perikanan yang lestari dan berkesinambungan. 


\section{UCAPAN TERIMA KASIH}

Tulisan ini merupakan kontribusi dari hasil kegiatan tim peneliti BPPL dan teknisi kapal KR. Bawal Puth III pada kegiatan penelitian Karakteristik Biologi Perikanan, Habitat Sumber Daya dan Produksi Sumber Daya Ikan di WPP NRI 712 T.A.2017, Balai Penelitian Perikanan Laut-Cibinong, Bogor.

\section{DAFTAR PUSTAKA}

Atmaja, S.B. dan D. Nugroho. 2012. Distribusi spasial upaya penangkapan kapal cantrang dan Permasalahannya di laut jawa. J. Lit. Perikan. Ind., 18(4):233-241. http://dx.doi.org/10.1 5578/jppi.18.4.2012.233-241

Badrudin, Aisyah, dan T. Ernawati. 2011. Kelimpahan stok sumber daya ikan demersal di perairan sub area Laut Jawa. J. Lit. Perik. Ind.,17(1):11-21. http://dx.doi.org/10.15578/jppi.17.1.2 011.11-21.

Balai Riset Perikanan Laut. 2015. Laporan kegiatan Tahun Anggaran 2015 WPP NRI 712 Laut Jawa. Balai Riset Perikanan Laut. 298 hlm.

Boer, M., K.A. Aziz, J. Widodo, A. Djamali, A. Ghofar, dan R. Kurnia. 2001. Potensi pemanfaatan dan peluang pengembangan sumberdaya ikan laut di Perairan Indonesia. Departemen Kelautan dan Perikanan dan Pusat Kajian Sumberdaya Pesisir dan Lautan. Bogor. 44 hlm.

Cinner, J.E., M.A. McNeil, X. Basurto, and S. Gelcich. 2013. Looking beyond the fisheries crisis: Cumulative learning from small-scale fisheries through diagnostic approaches. Global Environ. Change, 2(6):1359-1365.

De Robertis, A. and N.O. Handegard. 2012. Fish avoidance of research vessels and the efficacy of noisereduced vessels: a review. ICES J. of Marine Science, 70(1):34-45. http://dx.doi. org/10.1093/icesjms/fss155.
Direktorat Jenderal Perikanan Tangkap. 2015. Statistik perikanan tangkap di laut menurut wilayah pengelolaan perikanan negara Republik Indonesia (WPP-NRI). KKP. Jakarta. $340 \mathrm{hlm}$.

Direktorat Jenderal Perikanan Tangkap. 2014. Statistik perikanan tangkap di laut menurut wilayah pengelolaan perikanan negara Republik Indonesia (WPP-NRI). KKP. Jakarta. $220 \mathrm{hlm}$.

Effendi, M.I. 2002. Biologi perikanan. Yayasan Pustaka Nusantara. Jakarta. $163 \mathrm{hlm}$.

Ernawati, T. 2007. Distribusi dan komposisi jenis ikan demersal yang tertangkap Trawl pada musim barat diperairan utara Jawa Jengah. J. lktiologi Indonesia, 7(1):41-45.

Ernawati, T., Nuruludin, dan S.B. Atamaja. 2011. Produktivitas, komposisi hasil tangkapan dan daerah penangkapan jaring cantrang yang berbasis di PPP Tegalsari, Tegal. J. Lit. Perik. Ind., 17(3):193-200. http://dx.doi.org/10. 15578/jppi.17.3.2011.193-200.

Gulland, J.A. 1983. Fish stockassessmentamanual of basic methods. John Wiley and Sons. New York. 223 p.

Hilborn, R., J.M. Orensanz, Lobo, and A.M. Parma. 2005. Institutions, incentives and the future of fisheries. Philosophical Transaction of the Royal Society. 47-57 pp.

Hjellvik, V., K. Michalsen, A. Aglen, and O. Nakken. 2003. An attempt at estimating the effective fishing height of the bottom trawl using acoustic survei recordings. ICES J Mar Sci., 60:967-979. https://doi.org/10.1016/ S1054-3139(03)00116-4.

Kementerian Kelautan dan Perikanan. 2016. Keputusan menteri kelautan dan perikanan nomor: 47/kepmen$\mathrm{kp} / 2016$ tentang estimasi potensi, jumlah tangkapan yang diperbolehkan dan tingkat pemanfaatan sumber daya ikan di wilayah pengelolaan 
perikanan negara Republik Indonesia. KKP. Jakarta. 6 hlm.

Kementerian Kelautan dan Perikanan. 2015.

Peraturan menteri kelautan dan perikanan republik indonesia nomor per.02/men/2015 tentang larangan penggunaan alat penangkapan ikan pukat hela (trawls) dan pukat tarik (seine nets) di wilayah pengelolaan perikanan negara Republik Indonesia. KKP. Jakarta. $10 \mathrm{hlm}$.

Kementerian Kelautan dan Perikanan. 2014. Peraturan menteri kelautan dan perikanan republik indonesia nomor per.18/men/2014 tentang wilayah pengelolaan perikanan Republik Indonesia. KKP. Jakarta. $456 \mathrm{hlm}$.

Kloser, R.J., J.A. Koslow, and A. Williams. 1996. Acoustic assessment of the biomass of a spawning aggregation of orange roughy (Hoplostethus atlanticus, Collect) off South-eastern Australia, 1990-93. Marine and Freshwater Research, 47:1015-1024.

Korneliussen, R.J., Y. Heggelund, I.K. G.O. Eliassen, and Johansen. 2009. Acoustic species identification of schooling fish. ICES J Mar Sci, 66, 1111-1118. https://doi.org/10.1093/ icesjms/fsp119.

Lee, D.J. 2012. Fish length dependence of target strength for black porgy and fat greenling at two frequencies of 70 and $120 \mathrm{kHz}$. J. Kor Soc Fish Techno., 48:137-146.

Ma'mun, A., A. Priatna, T. Hidayat, dan Nurulludin. 2017. Distribusi dan potensi sumber daya ikan pelagis di wilayah pengelolaan perikanan negara Republik Indonesia 573 (WPP NRI 573) Samudera Hindia. J. Lit. Perik. Ind. 23(1):47-56. http://dx.doi. org/10.15578/jppi.23.1.2017.47-56.

Priatna, A. 2014. Kombinasi metode akustik dan survei trawl untuk meningkatkan akurasi perhitungan densitas ikan demersal di perairan tarakan. Institut Pertanian Bogor. Bogor. $89 \mathrm{hlm}$.

Shabangu, F., I. Hamton, J.C. Coetzee, and A.L. Ochoa, 2014. Hydro-acoustic technology and its application to marine science in South Africa. In: Reflections on the State of Research and Development in the Marine and Maritime Sectors in South Africa, Council for Scientific and Industrial Research, Pretoria, South Africa. 122- 152 pp.

Simmonds, E.J. and D. N MacLennan. 2005. Fisheries acoustic: theory and practice $2^{\text {nd }}$ ed. Blackwell Science Ltd. UK. 376 p.

Sparre, P. and S.C. Venema. 1998. Introduction to tropical fish stock assessment. FAO Fisheries Technical Paper. Roma. 45 p.

Widodo, J., K.A. Aziz, B.E. Priyono, G.H. Tampubolon, N. Naamin, dan A. Djamali. 1998. Potensi dan penyebaran sumberdaya ikan laut di perairan indonesia. Komisi Nasional Pengkajian Stok Sumberdaya Ikan Laut. LIPI. Jakarta. $251 \mathrm{hlm}$.

Wigan, M. 1998. The last of the hunter gatherers (fisheries crisis at sea). Swan Hill Press. London. 270 p.

Winger, P.D., S. Eayrs, and C.W. Glass. 2010. Fish behavior near bottom trawls. behavior of marine fishes capture processes and conservation challenges. Blackwell Publishing Ltd. 67-104 pp.

Yulianto, G., K. Suwardi, L. Adrianto, dan Machfud. 2016. Status pengelolaan sumberdaya ikan demersal sekitar pantai di Kabupaten Indramayu, Jawa Barat. Omni-Akuatika, 12(3):1-10. http://dx.doi.org/10.20884/1.oa.2016. 12.3.113.
Diterima
: 06 Juli 2018
Direview
: 10 Juli 2018
Disetujui : 05 Agustus 2018 
